\title{
Extending shelf life of fresh minced camel meat at ambient temperature by Lactobacillus dlbrueckii subsp. Delbrueckii
}

\author{
Ichraq Kalalou \\ Department of Biology \\ College of Sciences \\ Ibn Toufail University, BP 133 Kénitra, Morocco \\ E-mail: ichraq_kalalou@yahoo.fr \\ Mohamed Faid * \\ Department of Food Engineering and Technology \\ Hassan II Institute of Agronomy and Veterinary Medicine \\ PO Box 6202 Rabat-Institute, Morocco \\ Tel: $212-71047171$ \\ Fax: 212- 37778135 \\ E-mail:m.faid@iav.ac.ma \\ Ahmed Touhami Ahami \\ Department of Biology \\ College of Sciences \\ Ibn Toufail University, BP 133 Kénitra, Morocco \\ E-mail: ahami40@hotmail.com
}

Keywords: health biopreservative strains, meat, quality, spoilage, stabilization.

Studies were conducted to stabilize minced meat by fermentation using mixed lactic acid bacteria cultures isolated from natural fermented foodstuffs and selected for their antimicrobial activity against some hazardous microorganisms. Fresh meat of camel purchased from the slaughterhouse of Rabat (Morocco) was minced separately with a meat mincer and supplied with $5 \%$ glucose, then inoculated with lactic acid bacteria. Microbiological analyses were carried out to determine standard plate count (SPC), staphylococci, coliforms, enterococci, and lactic acid bacteria. All analyses were determined after 1, 2, 3, 4 and 7 days during the storage. Results showed that a low $\mathrm{pH}$ of 4.0-4.2 can be achieved (within 3 days at $22^{\circ} \mathrm{C}$ ), with a drastic reduction in SPC, coliforms, enterococci and staphylococci. Results suggested that the use of lactic acid bacteria would help in preserving fresh camel meat for extended periods at $22^{\circ} \mathrm{C}$.

Highly perishable foods such as meat provide excellent conditions for the growth of hazardous microorganisms. Microbial contamination can lower the quality of fresh minced camel meat; shorten its shelf life and result in economic loss and probably health hazards.

Biopreservatives such as lactic acid bacteria (LAB) and their metabolites had been investigated by several authors (Buncic et al. 1997; Sakhare and Narasimha Rao, 2003). Considerable research has been done on the ability of LAB to inhibit growth of pathogenic microorganisms (Winkowski et al.1993; Minor-Pérez et al. 2004). The capability of these bacteria to control growth of spoilage microorganisms has not been investigated to the same extent. To be successful in biopreservation, a bacteriocinogenic LAB culture must compete with the relatively high indigenous microbial loads of raw meat, to actively inhibit pathogenic and spoilage bacteria (Sakhare and Narasimha Rao, 2003; Minor-Pérez et al. 2004).

Several methods have been used to preserve meat including cooking, fermenting, salting, smoking and drying. Fermentation is an inexpensive method for preservation of meat and meat products. Acid formation (low pH), $\mathrm{H}_{2} \mathrm{O}_{2}$ and bacteriocins produced by starter cultures are responsible for preventing the growth of food poisoning and spoilage bacteria in meat (Krõckel, 1995; Budde et al. 2003). It was reported that the shelf-life of meat could be extended by low temperatures combined with a treatment with LAB strain (Babji and Murthy, 2000).

Several studies have been carried out on the physicalchemical characteristics, sensory proprieties and nutritive values of camel meat (El-Faher et al. 1991; Elgasim and Al-Kanhal, 1992). Up to now, no data have been published on the preservation and extension of the shelf life of minced camel meat by using LAB or their metabolites except the use of some organic acid salts combined with Bifidobacterium by Al-Sheddy et al. (1999). The aim of

\footnotetext{
Corresponding author
} 


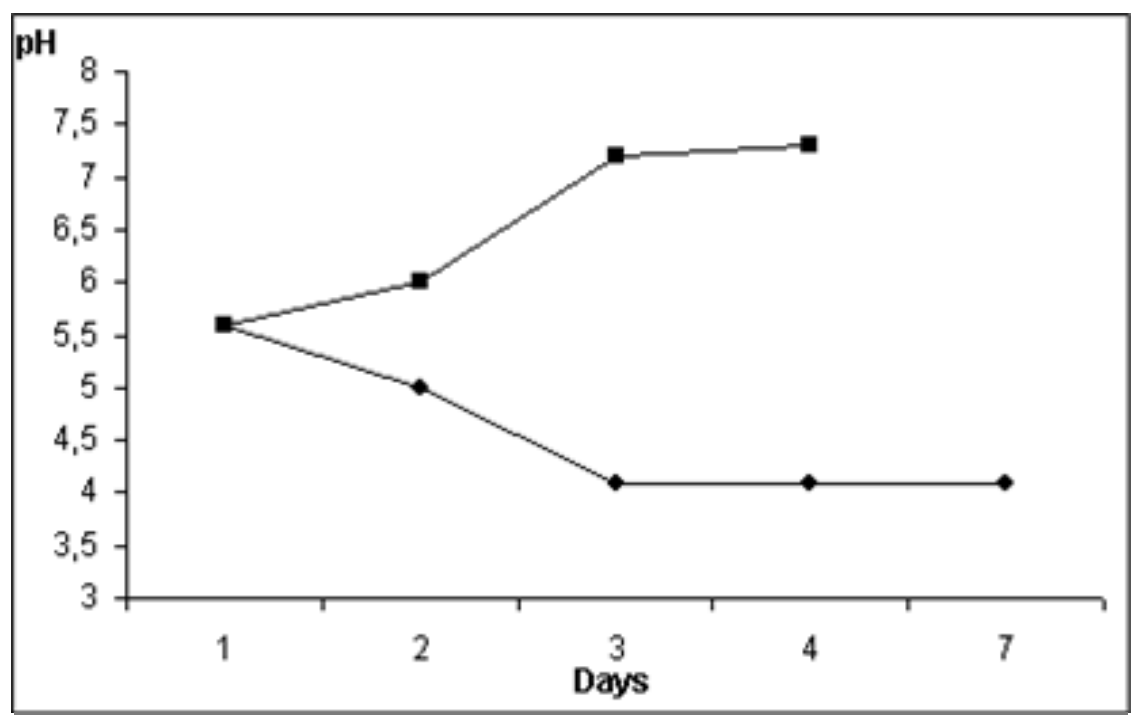

Figure 1. pH decrease pattern in inoculated and non-inoculated minced camel meat during fermentation at $22^{\circ} \mathrm{C}$.

this study was to investigate the possibility of extending the shelf life of fresh camel meat using Lactobacillus delbrueckii subsp. delbrueckii isolated from Moroccan foodstuffs, and selected for their inhibitory activity on Gram-negative and Gram-positive bacteria.

\section{MATERIALS AND METHODS}

\section{LAB isolation}

Ten samples of camel meat were collected from different butcher's shop in Morocco and transported to the laboratory using a refrigerated box $\left(4^{\circ} \mathrm{C}\right)$ and analyzed on arrival. LAB were isolated by homogenizing a $10 \mathrm{~g}$ subsample of each sample for $2 \mathrm{~min}$ in $90 \mathrm{ml}$ of saline solution $(8.5 \mathrm{~g} \mathrm{NaCl} / 1)$, and plating appropriate serial dilutions onto Man Rogosa Sharp (MRS) agar. Duplicate plates were incubated aerobically at $30^{\circ} \mathrm{C}$ for $48 \mathrm{hrs}$. Once single colonies were obtained they were inoculated in the appropriate broth. After growing the cultures were diluted and tested for purity on the suitable agar medium. All bacterial stock cultures were stored at $-80^{\circ} \mathrm{C}$ in MRS broth (Difco Laboratories, Detroit, MI) containing 16\% (v/v) glycerol.

\section{In vitro inhibition}

LAB strains isolated from camel meat were selected on the basis of their inhibitory activities on various Gram - and Gram + bacteria to select the most efficient strain to be used in meat preservation.

The antimicrobial activity of the isolated strains on Escherichia coli (4 strains), Pseudomonas aeruginosa (4 strains), Klebsiella pneumoniae (4 strains), Staphylococcus aureus (4 strains), Citrobacter freundii (2 strains), Bacillus subtilis (1 strain), Bacillus megaterium (1 strain), Bacillus cereus (3 strains) were determined by the well diffusion assay (Schillinger and Lücke, 1989). For the detection of antibacterial activity of the LAB strains, MRS broth (Difco, USA) was used. Ten $\mathrm{ml}$ of MRS broth was inoculated with each LAB strains and were incubated at $30^{\circ} \mathrm{C}$ for $48 \mathrm{hrs}$. After incubation, a cell-free solution was obtained by centrifuging $(6000 \times \mathrm{g}$ for $15 \mathrm{~min})$ the culture, followed by filtration of the supernatant through a $0.2 \mu \mathrm{m}$ pore size filter thus obtaining cell-free filtrates. The pathogenic test bacteria were incubated in Brain Heart Infusion (BHI) broth (Difco, USA) at appropriate temperature for $24 \mathrm{hrs}$. Petri dishes with $20 \mathrm{ml}$ of Muller Hinton agar were prepared, previously inoculated with $0.1 \mathrm{ml}$ of a $24 \mathrm{hrs}$ broth culture of pathogen microorganisms. Once solidified, the dishes were stored for $2 \mathrm{hrs}$ in a refrigerator. Four wells (ø6 mm) were then made and filled using $100 \mu \mathrm{l}$ of cell-free filtrate. The inoculated plates were incubated for $24 \mathrm{hrs}$ at $37^{\circ} \mathrm{C}$, and the diameter of the inhibition zone was measured with calipers in $\mathrm{mm}$. The antimicrobial activity was determined by measuring the clear zone around the colonies.

\section{Characterization and identification of the selected strain}

One of the most efficient strains was chosen to carry out this study. The isolate was Gram-stained and tested for catalase reaction. The isolate was then characterized by its growth at various temperatures $\left(10,15,45^{\circ} \mathrm{C}\right)$, tolerance of different salt levels $(2 \%, 4 \%$, and $6.5 \% \mathrm{NaCl})$, production of gas from glucose, dextran from sucrose and hydrolysis of arginine. The carbohydrate fermentation profiles of the selected isolate were investigated using API $50 \mathrm{CH}$ strips according to manufacturer's instructions (API system, BioMerieux, France). 
Table 1. Antibacterial activity detected in supernatant fluid of MRS broth from Lactobacillus delbrueckii subsp. delbrueckii by agar well diffusion assay.

\begin{tabular}{|c|c|c|c|}
\hline & \multicolumn{2}{|l|}{ Strains } & Zone diameter $(\mathrm{mm})$ \\
\hline \multirow{14}{*}{ 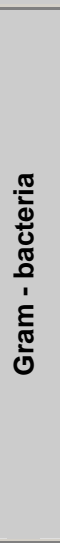 } & \multirow{4}{*}{ Escherichia coli } & 1 & 2.8 \\
\hline & & 2 & 2 \\
\hline & & 3 & 2.1 \\
\hline & & 4 & 1.9 \\
\hline & \multirow{4}{*}{ Pseudomonas aeruginosa } & 1 & 1.8 \\
\hline & & 2 & 1.7 \\
\hline & & 3 & 1.7 \\
\hline & & 4 & 2 \\
\hline & \multirow{4}{*}{ Klebsiella pneumoniae } & 1 & 1.6 \\
\hline & & 2 & 1.4 \\
\hline & & 3 & 1.5 \\
\hline & & 4 & 1.4 \\
\hline & \multirow{2}{*}{ Citrobacter freundii } & 1 & 1.4 \\
\hline & & 2 & 1.6 \\
\hline \multirow{9}{*}{ 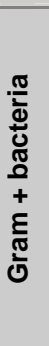 } & \multirow{4}{*}{ Staphylococcus aureus } & 1 & 1.5 \\
\hline & & 2 & 1.6 \\
\hline & & 3 & 1.3 \\
\hline & & 4 & 1.7 \\
\hline & \multirow{5}{*}{\begin{tabular}{|l} 
Bacillus subtilis \\
Bacillus megaterium \\
Bacillus cereus. 1 \\
Bacillus cereus. 2 \\
Bacillus cereus. 3
\end{tabular}} & 1 & 2.5 \\
\hline & & 2 & 1.7 \\
\hline & & 3 & 2.7 \\
\hline & & 4 & 1.7 \\
\hline & & 5 & 1.5 \\
\hline
\end{tabular}

\section{Meat system}

Camel meat was purchased from the retail in Rabat (Morocco). Amounts of $1 \mathrm{~kg}$ each were deboned and sliced. Fresh camel meat was minced with a sterile meat mincer in a sterile flask and the $\mathrm{pH}$ was checked before inoculating.

\section{Meat inoculation}

The selected strain identified as L. delbrueckii subsp. delbrueckii was grown on MRS for $24 \mathrm{hrs}$ at $30^{\circ} \mathrm{C}$. From this culture dilutions up to $10^{-6}$ were plated on MRS to determine the cell concentration. The amount used to inoculate meat was around $107 \mathrm{cfu} / \mathrm{g}$.

Glucose $(5 \% \mathrm{w} / \mathrm{w})$ was mixed with the minced meat. The inoculated meat was introduced in sterile plastic bags and stored at $22^{\circ} \mathrm{C}$. The control (minced meat without addition of glucose and lactic culture) was stored under the same conditions.

\section{Physico-chemical determinations}

$\mathrm{pH}$ : $\mathrm{pH}$ of the samples was measured by a $\mathrm{pH}$ meter apparatus (Crison MicropH 2000).

\section{Microbiological determinations}

Samples (10 to $15 \mathrm{~g}$ ), were cut into small pieces and blended in $90 \mathrm{ml}$ of saline water $(8.5 \mathrm{~g} \mathrm{NaCl} / 1)$ to make the initial dilution $\left(10^{-1}\right)$. Serial dilutions up to $10^{-6}$ were then prepared. Standard plate count (SPC) was determined by plating appropriate dilutions on plate count agar (Difco, USA). The plates were incubated at $30^{\circ} \mathrm{C}$ for $48 \mathrm{hrs}$. LAB were plated on MRS (Difco, USA), incubated at $30^{\circ} \mathrm{C}$ for $48 \mathrm{hrs}$. Enterococci were determined on liquid media using 3 tubes per dilution. Appropriate dilutions were inoculated into Azide dextrose Broth (Difco, USA), incubated at $30^{\circ} \mathrm{C}$ for $24 \mathrm{hrs}$. Tubes that had shown growth were transferred on Ethyl Violet Azide Broth (Difco, USA) and incubated at $37^{\circ} \mathrm{C}$ for $24 \mathrm{hrs}$. Tubes that had shown growth and formation of a violet precipitation in the bottom of tubes were counted. The number of positive tubes was reported to the table for the most probable number. Staphylococci were determined on Mannitol Salt Agar (Merck, Germany), the plates were incubated at $37^{\circ} \mathrm{C}$ for $24 \mathrm{hrs}$.

\section{RESULTS}

The strain of $L$. delbrueckii subsp. delbrueckii was first tested on different strains of Gram + and Gram - bacteria to study the inhibitory effects (Table 1). The strains was inhibitory to all the strains tested which showed the almost the same sensitivity. All the diameters of the inhibition zones were in the range of 1.4 to $2.8 \mathrm{~cm}$.

Results about the in vivo assay showed a $\mathrm{pH}$ drop from 5.5 to 4.0-4.2. This was achieved in 3 days incubation at 


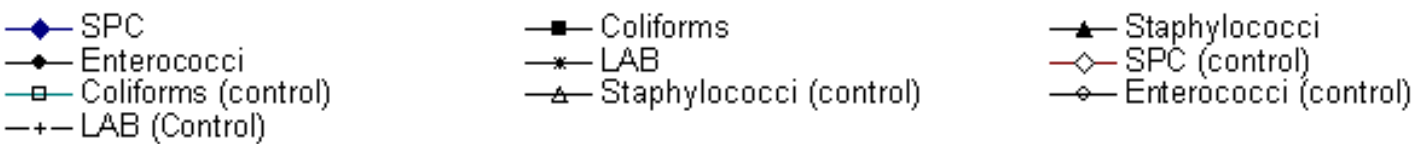

\section{$\log$ CFUig}

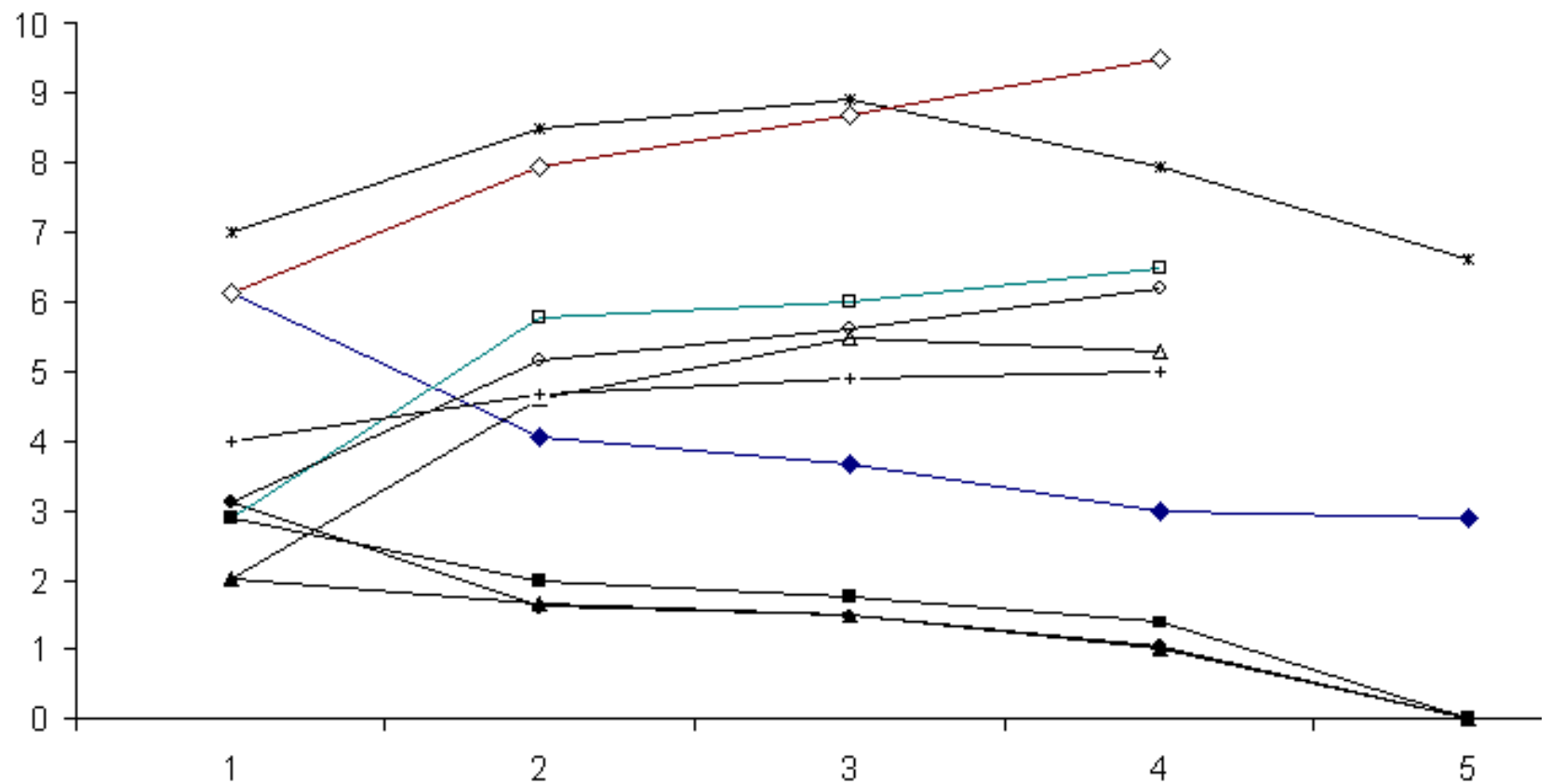

Figure 2. Changes in SPC, coliforms, staphylococci, enterococci and LAB profiles in inoculated and non-inoculated minced camel during fermentation at $22^{\circ} \mathrm{C}$.

ambient temperature (Figure 1). In the non-inoculated assay (control) the $\mathrm{pH}$ was around 7.2 after the same period. This may lead to a severe deterioration of meat leading to an offodour appearance and many other changes in the meat. The $\mathrm{pH}$ decrease in the inoculated assay is due to the lactic acid formation by $\mathrm{LAB}$. The $\mathrm{pH}$ decrease to $4-4.2$ is related to the formation of the lactic acid in the medium. The microbial profiles including SPC, coliforms, staphylococci, enterococci and LAB for the inoculated assay and the control are reported in figure 2. SPC were decreased by approximately $2 \log$ units during the first $24 \mathrm{hrs}$ in the inoculated assay. The initial SPC of the mixture was around $1.4 \times 10^{6} \mathrm{cfu} / \mathrm{g}$, which decreased to $1.2 \times 10^{4} \mathrm{cfu} / \mathrm{g}$ after 24 hrs and $8 \times 10^{2} \mathrm{cfu} / \mathrm{g}$ after 7 days of incubation at the ambient temperature $\left(22^{\circ} \mathrm{C}\right)$.

The same decrease pattern was also observed for the coliforms. Coliforms were reduced from $8 \times 10^{2} \mathrm{cfu} / \mathrm{g}$ to $10^{2} \mathrm{cfu} / \mathrm{g}$ after $24 \mathrm{hrs}$ and to less than $1 \mathrm{cfu} / \mathrm{g}$ after 7 days storage. It is interesting to note that the level of coliforms was reduced from the start of inoculation and development of an off-odour was prevented during storage of meat.

Not only coliforms would induce changes in meat but also many other groups of microorganisms may cause deteriorations in fresh meat such as staphylococci, enterococci and others. A net decrease of the counts compared to the control was observed and populations reached low levels being less than $1 \mathrm{cfu} / \mathrm{g}$ in the assay but they reached $10^{5} \mathrm{cfu} / \mathrm{g}$ in the control. The prevention of staphylococci in meat is very beneficial for the quality of fresh meat since these microorganisms may induce lipolysis and proteolysis reactions in the product leading to an off flavour. Enterococci are also ubiquitous microorganisms, which can grow in meat at high temperature. The same pattern as coliforms was observed. Enterococci numbers decreased from $4 \times 10^{3} \mathrm{cfu} / \mathrm{g}$ to $40 \mathrm{cfu} / \mathrm{g}$ after $24 \mathrm{hrs}$ and to less than $1 \mathrm{cfu} / \mathrm{g}$ after 7 days, while the control showed a high level being $10^{5} \mathrm{cfu} / \mathrm{g}$. LAB counts in the sample from the initial mixture $\left(\mathrm{t}_{\mathrm{o}}\right)$ may tell about the level of the inoculation $\left(10^{7} \mathrm{cfu} / \mathrm{g}\right)$ in the sample. Counts in the inoculated assay were higher than the control, indicating a difference in physico-chemical changes in meat and consequently in the undesirable microbial load.

\section{DISCUSSION}

Fresh meat and fresh meat products are susceptible to 
biochemical changes due to the microbial growth at ambient temperatures, which are high in some countries (20 to $30^{\circ} \mathrm{C}$ in Morocco). Minced meat is widely consumed in Morocco as a popular product called Kefta. This is exhibited at ambient temperature in retail and restaurants. Deterioration may occur fastly because of the high contamination, mincing and the high ambient temperature. It should be also assumed that all process used to extend the shelf life of fresh meat are based on low temperature (refrigerating or freezing). This may not be the case for fresh meat products exhibited in retail. Biological processes would be more efficient and safe to handle in this case such as the use of LAB to delay or to stop the spoilage microorganisms.

Vold et al. (2000) showed that the presence of a large number of background bacteria (LAB) in the ground meat inhibited the growth of E. coli O157:H7 both aerobically and anaerobically at $12^{\circ} \mathrm{C}$. In a recent work (Minor-Pérez et al. 2004), pork meat samples inoculated with either Staphylococcus carnosus or Lactobacillus alimentarius showed a $\mathrm{pH}$ reduction from 6.4 to 5.5 within $24 \mathrm{hrs}$ when stored at $20^{\circ} \mathrm{C}$ and in the fourth day reached a $\mathrm{pH}$ of 4.65 for the first strain and a value of 4.85 for the second one. The inhibition of lactic acid on several pathogens and spoilage microorganisms have previously been reported (Guerrero and Taylor, 1994; Okolocha and Ellerbroek, 2004).

Several authors reported the use of LAB as biopreservatives at refrigeration temperatures and subtropical temperatures (Guerrero and Taylor, 1994; Minor-Pérez et al. 2004). In these studies, after the fermentation was started at $20^{\circ} \mathrm{C}$, samples were stored under refrigeration and the growth of spoilage microorganisms and pathogens was prevented. In the case of subtropical climates or conditions of temperature abuse, temperatures above $20^{\circ} \mathrm{C}$ are expected. The $\mathrm{pH}$ reduction due to acid production could reduce the growth rate of undesirable strains (Helander et al. 1997).

As reported by Minor-Pérez et al. (2004) at $24 \mathrm{hrs}$ of storage, enterobacteria populations were below $10^{4} \mathrm{cfu} / \mathrm{g}$ in pork meat inoculated with S. carnosus and stored at $20^{\circ} \mathrm{C}$, and below $10^{5} \mathrm{cfu} / \mathrm{g}$ in samples inoculated with $L$. alimentarius at $20^{\circ} \mathrm{C}$.

Our results are similar to those reported by Sakhare and Narasimha Rao (2003) who showed that the use of a mixture of LAB could extend the shelf life of minced meat at high temperatureand inhibited the growth of pathogenic microorganisms. The desired $\mathrm{pH}$ was in the range 4.0-4.2. These values were reached after $24 \mathrm{hrs}$ in minced meat stored at $37^{\circ} \mathrm{C}$ and in $30 \mathrm{hrs}$ in minced meat incubated at $30^{\circ} \mathrm{C}$. In the present study, the desired $\mathrm{pH}$ (4.1) was achieved after 3 days.
The desirable low $\mathrm{pH}(4.0-4.2)$ can be achieved faster for stabilization of meat incubated at ambient temperature using a LAB culture. Inhibition or reduction of spoilage and food poisoning microorganisms was demonstrated in meat during storage at high temperatures. The data generated in the present study is useful in hot countries like Morocco where refrigeration facilities are not available or inadequate especially to preserve camel meat or meat of other species for a long time. This procedure for preservation can also be used to improve sanitarian conditions in rural butcheries or popular restaurants when minced meat is exposed to sale at ambient temperature.

\section{REFERENCES}

AL-SHEDDY, I.; AL-DAGAL, M. and BAZARAA,W.A. Microbial and sensory quality of fresh camel meat treated with organic acid salts and/or bifidobacteria. Journal of Food Science, March/April 1999, vol. 64, no. 2, p. 336-339.

BABJI, Y. and MURTHY, T.R.K. Effect of inoculation of mesophilic lactic acid bacteria on microbial and sensory changes of minced goat meat during storage under vacuum and subsequent aerobic storage. Meat Science, April 2000, vol. 54, no. 2, p. 197-202.

BUDDE, B.B.; HORNBÆK, T.; JACOBSEN, T.; BARKHOLT, V. and KOCH, A.G. Leuconostoc carnosum 4010 has the potential for use as a protective culture for vacuum-packed meats: culture isolation, bacteriocin identification, and meat application experiments. International Journal of Food Microbiology, June 2003, vol. 83, no. 2, p. 171-184.

BUNCIC, S.; AVERY, S.M. and MOORHEAD, S.M. Insufficient antilisterial capacity of low inoculum Lactobacillus cultures on long-term stored meats at $4^{\circ} \mathrm{C}$. International Journal of Food Microbiology, February 1997, vol. 34, no. 2, p. 157-170.

EL-FAHER, M.Z.; RAWDAH, T.N.; ATTAR, K.M. and DAWSON, M.V. Mineral and proximate composition of meat of the one humped camel (Camelus dromadarius). Food Chemistry, March 1991, vol. 42, no. 2, p. 139-143.

ELGASIM, E.A. and ALKANHAL, M.A. Proximate composition, amino acids and inorganic mineral content of Arabian Camel meat: comparative study. Food Chemistry, January 1992, vol. 45, no. 1, p. 1-4.

GUERRERO I. and TAYLOR, A.J. Meat surface decontamination using lactic acid from chemical and microbial sources. Lebensmittel Wissenschaft und Technologie, June 1994, vol. 27, no. 3, p. 201-209.

HELANDER, I.M.; VON WRIGHT, A. and MATTILA- 
SANDHOLM, T.M. Potential of lactic acid bacteria and novel antimicrobials against Gram-negative bacteria. Trends in Food Science and Technology, May 1997, vol. 8, no. 5 , p. 146-150.

KRÕCKEL, L. Bacterial fermentation of meats. In: CAMPBELL PLATT G. and COOK, P.E. eds. Fermented Meats. Blackie Academic and Professional, Glasgow, UK, 1995, p. 69-109.

MINOR-PÉREZ, H.; PONCE-ALQUICIRA, E.; MACÍASBRAVO, S. and GUERRERO-LEGARRETA, I. Changes in fatty acids and microbial populations of pork inoculated with two biopreservative strains. Meat Science, April 2004, vol. 66 , no. 4 , p. 793-800.

OKOLOCHA E.C. and ELLERBROEK, L. The influence of acid and alkaline treatments on pathogens and the shelf life of poultry meat. Food Control, In Press.

SAKHARE, P.Z. and NARASIMHA RAO, D. Microbial profiles during lactic fermentation of meat by combined starter cultures at high temperatures. Food Control, January 2003, vol. 14, no. 1, p. 1-5.

SCHILLINGER, U. and LÜCKE, F.K. Antibacterial activity of Lactobacillus sake isolated from meat. Applied and Environmental Microbiology, August 1989, vol. 55, no. 8, p. 1901-1906.

VOLD, L.; HOLCK, A.; WASTESON, Y. and NISSEN, H. High levels of background flora inhibits growth of Escherichia coli $\mathrm{O} 157: \mathrm{H} 7$ in ground beef. International Journal of Food Microbiology, June 2000, vol. 56, no. 2-3, p. 219-225.

WINKOWSKI, K.; CRANDALL, A.D. and MONTVILLE, T.J. Inhibition of Listeria monocytogenes by Lactobacillus bavaricus $\mathrm{MN}$ in beef systems at refrigeration temperatures. Applied Environmental Microbiology, August 1993, vol. 59, no. 8, p. 2552-2557. 